\title{
OBITUARY
}

\section{PROFESSOR J. G. C. ANDERSON}

(Plate XviII)

Though it is not customary to publish obituaries in this journal, the death of Professor J. G. C. Anderson on 3 Ist March, 1952, at the age of eighty-one, should not be allowed to pass unnoticed here ; for he had been a consistent friend of the Society since its formation, and his contributions to the study of the ancient world, and particularly to the discovery and interpretation of the inscriptions of Asia Minor, were such as to make useful a list of his more important publications.

Of his life it is not the purpose of this note to speak at length, nor is it likely that he would have wished it done ; for he was among the most unassuming of men. A son of the Manse, he was one of the distinguished children of the Rev. Dr. Alexander Anderson, of Edinkillie, Morayshire. At the University of Aberdeen he fell under the influence of (Sir) W. M. Ramsay, then Professor of Humanity, and from him he acquired the interest in $A$ sia Minor which eventually led him, with restrained enthusiasm for the amenities of Anatolian travel, to pay repeated visits to that region. Moving from Aberdeen to Oxford as a Scholar of Christ Church, where he came to know F. J. Haverfield, whose effect on his life was not less strong than Ramsay's, he took two First Classes in the Classical School and then was elected to a Craven Fellowship which made possible his first visit to Greece in I896. Thereafter, having become a Research Fellow of Lincoln College, he was in Asia Minor in each of the following years up to 1900 , and again in 1912, when he was with Ramsay and Professor W. M. Calder at Yalowadj. It was a journey in Pontus in 1899, along a route followed soon afterwards by Franz Cumont, who later sought the acquaintance of the precursor about whom he had heard much from the local inhabitants, that led to the collaboration of these two scholars in the volumes of Studia Pontica.

In 1900 Anderson was elected to a Tutorial Studentship at Christ Church, where at first he taught mainly for Classical Moderations ; but later, when Haverfield left to become Camden Professor, he took over the responsibility for Roman History in the Final School. He will be remembered by many generations of Christ Church men both as a painstaking tutor, with the highest standards of accuracy, and also, more widely, as a successful Censor, whose firmness was combined with a sympathetic understanding of the interests and aberrations of youth. And a still larger Oxford public will treasure the recollection of his meaty lectures on ancient Rome and of the unexpected turns of phrase and the rich Scottish intonation by which they were adorned.

When (Sir) Henry Stuart Jones ceased to be Camden Professor in 1927 Anderson succeeded him and moved to Brasenose, where he remained until he reached the age of retirement in 1936 . Thereafter he continued to live in Oxford, with the widowed sister who had been his companion for many years, until his death.

So far as his work was concerned Anderson was occupied from early manhood with the study of Roman history ; but his special interests changed. At first he concentrated on the epigraphy of Asia Minor : after Haverfield's death in I9I9 he turned to Tacitus, having undertaken to complete the revision of Furneaux's edition of the Agricola, which Haverfield had begun, and from that being led on to the Germania. He was a meticulous scholar. In Asia Minor among his fellow voyagers it came to be assumed that a copy of a text made by Anderson was right ; and his editions of the Agricola and Germania combine sound philology with soberly competent interpretation in a way which deserves a more imposing format than the volumes in fact were given. But their value was not concealed from those who know, and such as had the privilege of his friendship must now regret the passing of a man who had the highest standards both in life and in learning, whose good nature was rarely hidden by his occasional discontent with the times, and whose readiness to help his younger colleagues, though never pressed on them, was always available.

Anderson was a member of the Council of our Society on its formation. In 1929 he became a Vice-President, but with the modesty which was perhaps too powerful an element in his character he refused to be considered for the Presidency. Nevertheless he took the liveliest interest in the Society's work, and showed it in his will by leaving, subject to a life- 
interest, a legacy of $£_{\mathrm{r}, 000}$ to form the nucleus of a fund of which the interest should be used in aid of the publication of the fournal.

The bibliography which follows was mainly put together by Mr. P. M. Fraser, to whom the thanks of the Editorial Committee are due. It does not set out to be complete and is intended only to record Anderson's work in Asia Minor and his chief publications in other fields. In particular, all but two or three of the many reviews he wrote have been omitted.

\section{BIBLIOGRAPHY}

AbBreviations

$B S A \quad$ Annual of the British School at Athens

$C A H$ Cambridge Ancient History

$C R \quad$ Classical Review

$D N B \quad$ Dictionary of National Biography

$\mathscr{F H S}$ Journal of Hellenic Studies

$\dddot{F R S}$ Journal of Roman Studies. (Articles in volumes issued later than the date they bear are placed under the year in which they were published.)

I 896

' The Campaign of Basil I against the Paulicians in A.D. 872.' $C R \times 13^{6-40 .}$

1897

'The Road-System of Eastern Asia Minor with the evidence of Byzantine Campaigns.' $\mathcal{F} H S$ xvii, $22-44$.

'A Summer in Phrygia, I.' $\mathfrak{F H S}$ xvii, 396-424. I 898

'A Summer in Phrygia, II.' $\mathscr{F H S}$ xviii, 8I-128.

'A Summer in Phrygia: some Corrections and Additions.' $7 H S$ xviii, 340-4.

'Exploration in Asia Minor during 1898 : first Report.' $B S A$ iv, $1897-8,49^{-78}$.

I 899

'Exploration in Galatia cis Halym, Part II : Topography, Epigraphy, Galatian Civilisation.' $\mathscr{J H S}$ xix, 52-r 34 ; $280-318$.

'Pontica.' $\mathscr{F} H S \mathrm{xx}, \mathbf{1} 5 \mathrm{I}-8$.

1900

I901

The Student's Gibbon : a History of the Decline and Fall of the Roman Empire, abridged from the original work by Sir W. Smith. A new and revised edition in two parts. Part II, from A.D. ${ }_{5} 65$ to the Capture of Constantinople by the Turks, by J. G. C. A. (London).

'A new Hittite Inscription.' $\mathfrak{F} H S$ xxi, 322-4.

Murray's Handy Classical Maps, Asia Minor (London).

1903

Studia Pontica I : a Fourney of Exploration in Pontus (Brussels).

1906

'Paganism and Christianity in the Upper Tembris Valley.' Studies in the History and Art of the Eastern Provinces of the Roman Empire, edited by W. M. Ramsay (Aberdeen), 183-227.

1910

'A Celtic Cult and two Sites in Roman Galatia.' $\mathcal{F} H S \mathrm{xxx}, 163_{-7}$

Contributions to Studia Pontica III (Brussels).

I9I I

'Trajan on the Quinquennium Neronis' (with a note by $F$. Haverfield). $\mathscr{F} R S$ i, r 73-9.

Numerous articles on Asia Minor in the eleventh edition of the Encycl. Brit. (1910-191 $)$ : in particular those on Galatia and Pontus. (For others v. Encycl. Brit. ${ }^{11}$ index of contributors under 'Anderson, John George Clark'.)

1912

'Three new Inscriptions from Pontus and Pisidia' (with F. Cumont). $\mathscr{F} R S$ ii, 233-6.

1913

' Festivals of Mên Askaênos in the Roman Colonia at Antioch of Pisidia.' $\mathscr{F R S ~ i i i , ~ 2 6 7 - 3 0 0 . ~}$

Obituary notice of F. Haverfield. CR xxxiii, $165^{-6}$.

1919

1920

'When did Agricola become Governor of Britain ?' $C R$ xxxiv, $158-61$.

1922

Cornelii Taciti de vita Agricolae, edited by H. Furneaux : second edition, revised and largely rewritten by J. G. C. A. (Oxford). 
1923

'Some Questions bearing on the Date and Place of Composition of Strabo's Geography.' Anatolian Studies presented to Sir William Ramsay (Manchester), I-13.

1924

'Pompey's Campaign against Mithradates.' $\mathscr{F} R S$ xii, 99-105.

1928

'Augustan Edicts from Cyrene.' $\mathscr{F R S}$ xvii, 33-48.

1932

'The Genesis of Diocletian's Provincial Re-organization.' $\mathscr{F} R S$ xxii, 24-32.

I 934

'The Eastern Frontier under Augustus.' $C A H \mathrm{x}$, ch. ix, 239-83.

' The Eastern Frontier from Tiberius to Nero.' $C A H \mathrm{x}, \mathrm{ch}$. xxii, $743-80$.

1936

Review and discussion of R. P. Robinson, The Germania of Tacitus (Middleton, Conn.). $\mathcal{Y} R S$ xxvi, $272-6$.

'An Imperial Estate in Galatia.' $\mathscr{F R S}$ xxvii, $18-21$.

1937

1938

Cornelii Taciti de origine et situ Germanorum, ed. J. G. C. A. (Oxford).

I 939

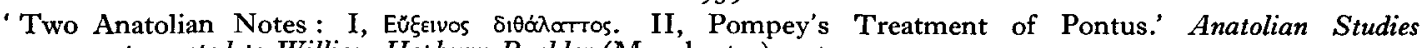
presented to William Hepburn Buckler (Manchester), $\mathrm{x}-7$.

Review and discussion of A. von Premerstein, Vom Werden und Wesen des Prinzipats (ABAW 1937). FRS xxix, 93-7.

Cornelii Taciti opera minora, recognovit brevique adnotatione critica instruxit Henricus Furneaux. . . Germaniam et Agricolam iterum recensuit J. G. C. A. (Script. Class. Bibl. Oxon.).

$194^{\circ}$

'Sir George Macdonald : a Bibliographical Supplement.' $\mathscr{F} R S$ xxx, I29-33.

I94I

Sir W. M. Ramsay, The Social Basis of Roman Power in Asia Minor (Aberdeen), prepared for the press by J. G. C. A.

1949

' Ramsay, Sir William Mitchell.' $D N B$ ı931-1940, 727-8.

1952

Review of J. Perret, Recherches sur le Texte de la 'Germamie' (Paris, 1950). $7 R S$ xlii, 138-9.

No bibliography of Anderson's writings would be complete without mention of the important services he rendered to scholarship in the preparation for the press of Professor Rostovtzeff's two major works-The Social and Economic History of the Roman Empire, Oxford, 1926 (v. p. xv), and The Social and Economic History of the Hellenistic World, Oxford, 1941 (v. pp. xii-xiii). 


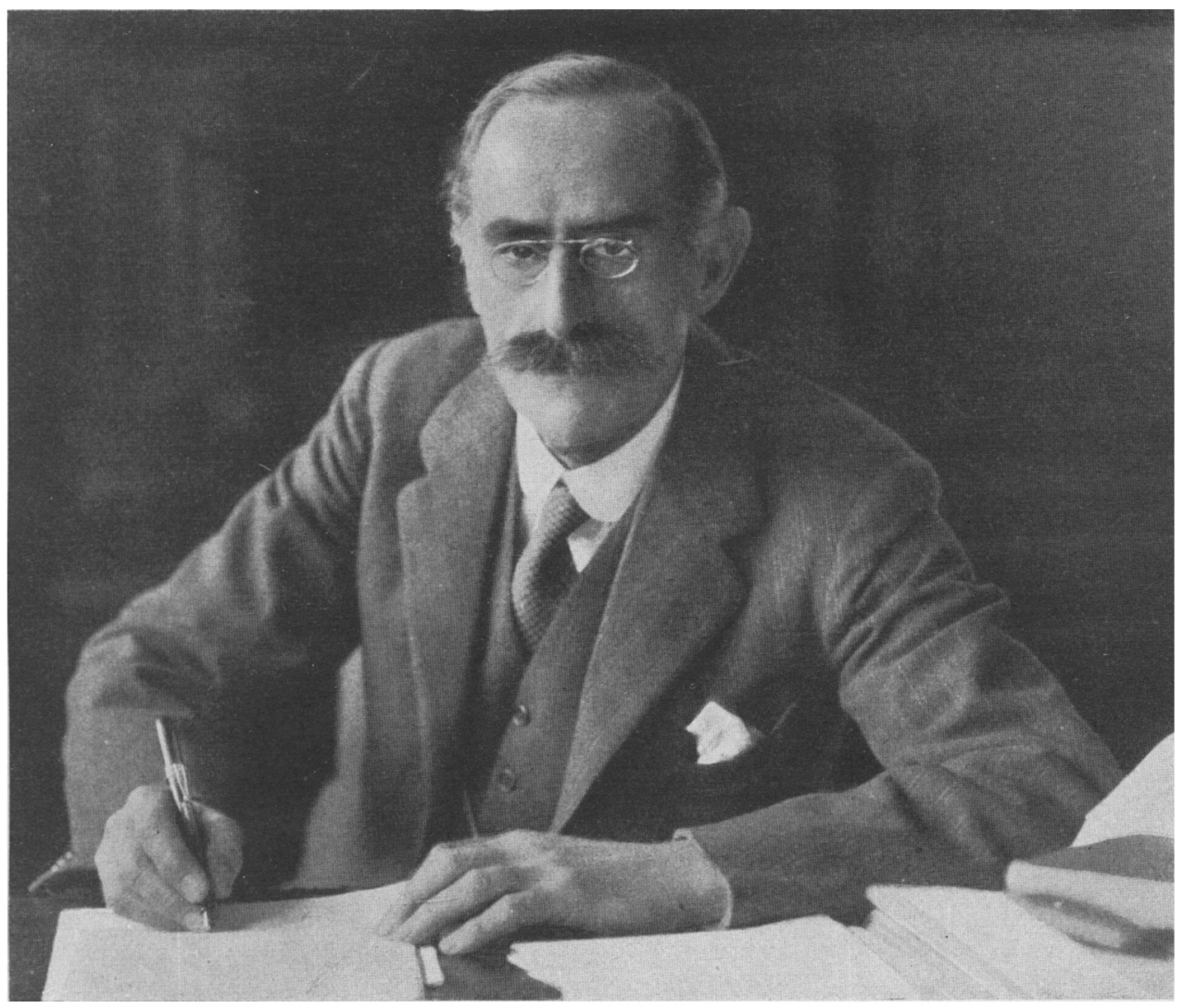

Lafayette Ltd., photographers

JRS vol, XIII (1952) plate XVII

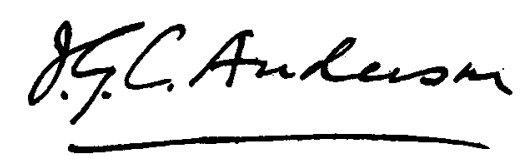

(see p. 110) 